\title{
Sønderjylland 1931.
}

Af $T$ hade Petersen.

\section{Grænsen.}

Den Bevægelse, der i det foregaaende Par Aar mærkedes i Retning af større Forstaaelse af Grxnsedragningens Retfardighed, fortsattes ogsaa i 1931 og voksede ojensynlig i styrke. I Begyndelsen af Maj fandt saaledes et dansk-tysk Pressebes $\emptyset$ Sted i Flensborg i Anledning af det forestaaende "Ostersøaar». Det foregik under meget forsonlige Former (H. 9. 5. Av. 9. 5.). ) Grænseforen ing en, hvis Medlemisantal er steget med 180 , anerkender ved sit Sendemandsmøde i Kolding paa ny uforbeholdent de Forhold, der skabtes ved Grænsedragningen og tager Afstand fra D. D. D. (H. 15.5., Gr. S. 156 ff.). Ved Granseforeningens Møde paa Skamlingsbanke udtaler Niels Kjems, at vi hellere vil have Muligheden for at vinde og tabe, end at leve $i$ ode. læggende Fjendskab med Mennesker, som nødvendige Interesser bin. der os til. (H. 18.5.). "Nis Mogensen“ og Ernst Schrøder glæder sig i "Nordschl. Ztg.» over Niels Kjems og Redaktor Christiansens Udtalelser paa Skamlingsbanke. (H. 2.6.). Formanden for Schl.-Holst.-Bund, Grardejer Iwersen, Munkbrarup, siger paa Knivsbjerg, at fælles Interesse gør Tilnærmelse mere og mere paakrævet. (H. 29.6.). Frnst Schrøder skriver ret forstaaende om dansk-tysk Nyorientering. (H. 31.8.). De tyske Landboforeningers Konsulent P. Asmussen tilraader en klar national Holdning, parret med absolut Agtelse for de anderledessindede og $\mathrm{i}$ det hele Samarbejde med Danskerne paa økonomisk Omraade. (H. 12.8.) Nyorienteringen vinder stadig Terran. Ogsaa Nis Mogensen erkender det. (H. 7.9.). Ved det sydjydske Samariterstævne i Sonderborg for nogen Tid siden var ogsaa Sanitetskolonnen fra Flensborg indbudt. (H. 15.9.). Den 2\%.9. skal der holdes en folles Øvelse ved Krusaa. (H. 15.9.).

") H. = Hejmdal 1931. Av, = Flensborg Avis 1931. L. \pm Nordslesvisk Landbrugs- og Mejeritidende 1931. Gr. = Grænsevagten 1931. Ber. = Trykt Beretning fra vedkommende Institution trykt 1931. 
Ind mellem disse forsonlige Roster lød der dog ogsaa andre. Dr. Alnor udsendte 21 Kort om Valg, Sindelag osv, men flere af dem var helt vildledende. (II. 20.6.). Tyske Konmmunister agtede at denonstrere ved Gransen. Det blev imidlertid forhindret af dansk saavel som tysk Politi (H. 3.8.), og mod Slutningen af Aaret rejstes i Schl.-Holst.-Bund det gamle Krav om Flytning af Grensen til Kongeaaen (H. 10.12.).

Frerds le n over Grensen er livlig. I 1930 passeredes den red Kollund, Krusaa, Padborg og Oksevejen af 1,200,000 Mennesker (II. 8.4.). Ad ulovlige Veje overskrides den ogsaa nu og da. B1. a. viste det sig, at Tyskere drev ulovlig Jagt paa den fredede $\varnothing$ Jordsand (H. 6. 2.)

\section{Nationalt Liv.}

a. I) a n s $\mathrm{Syd}$ for Grænsen.

Det danske Aarsinø de i Flensborg i 1931 var besogt af Mennosker. Den slesvigske Forenings Flensborgafdeling havde mistet 61 Medlemmer og havde nu 312, i Landkredsen var Antallet 500, i cottorp Ant 284, hvilket var 69 Fremgang (II. 8.6. Av. Nr. 131.).

I den danske $\mathrm{K}$ i r k e i Flensborg er der siden 19:1 (lobt 4t); Bum, konfirmeret 973, egteviot 176 Par og begravet 369 (H. 18. 5., Ar. Nr. 114. Ber. 1931.).

Af clanske sk o le r har Duborgskolen 35 É Elever, Tarup 13, Kobbermollen 16, Jaruplund 12, Langbjerg 14, Harrislevmark 21. Der er almindelig Fremgang i dem (H.6.5., Av. 6.5., Dansk Skoleforenings- og Duborgskolens Beretninger.). Gottorpskolens Statstilskud blev neisat fra $15,5 \pi 0$ til 13,910 M. (H. 18. 8.). Alligevel kunde der indvies on $\mathrm{YY}$ bygning til den danske Privatskole i slesvig By (Av. 1\%. 10., Gr. S. 405 ff.).

Af Bogs a ml ing an paa Flensborghus udlaantes 44,2501 Bind (deraf $24,8 \%$ Faglitteratur) til 13.34 Lamere. Lasesalen besggtes af 12,088 Voksne og $6861 \mathrm{Burn}$ (Boguntallet er vokset med 2 i80, deraf 1568 Gaver (Av. 1. 10.) Danske Forsamlingshuse (Gr. S. 73 ff.). Det danske Stemmetal ved Rigsthasvalget 14.9. 1930 gik en Del tilbage (Gr. 334 ff.).

$$
\text { b. Tysk Sy il for Grantr. }
$$

13 Skoleledere og Prester i Slesvig har angrebet den dansks Skolevirksomherl i Byou. De paastaar, at Skolen optager de daarligst 
hegiverle Elever (H. 17.6.) Regerings- og Skoleraad Ingwersen og Krodsskoleraad Johannsen i Slesvig tager imidlertid Afstand fra dem, Erust Schrøder ligeledes (H. 23.6.).

I ok on om is k IIensecnde staar det daarligt til. Flensborg Skibsvarft maatte lukke (II. 3.1.), og Byen maatte hen paa Sommeren udbetale Lonningerne i 4--5 Rater paa Grund af Pengemangel (II. 4.8.). Der oprettedes i 1930 i Sl.-Holst. 1153 Ejendomme med 14,367 ha nod 607 med 9323 ha $\mathrm{i} 1929$ (H. 31. 1.). De fleste "Vereine heimattreuer Nordschleswiger" har stillestaaende eller aftagenile Medlemstal. 26 af dem napvnes (H. 29. 5.).

\section{c. Tysk i Nordslesvig.}

Ved Nytaar forlod Dr. Rasch "Nordschl. Zeitung«, vistnok af politiske Grunde (H. 2.1.). Senere sluttedes alle t y s e Foreninger i Nordslesvig sammen til et Forbund (H. 7. 10.). Et Par Hijemmetyskere rr utilfreds rmed, at Formanden for Reichsverband d. deutschen Jugendhorberge ved Indvielsen af Longbehnhuset paa Knivsbjerg (Av. x. 4.) har talt om den gamle og den nye Tid (H. 9. 4.).

Voge lges a ng har i 1930 ydet 85 Laan til 521,340 Kr., og "Höfevrrwaltungsgesellschaft« har faaet tilskorlet 12 Ejendomme til 639,930 Kr. Ialt er der ydet 1666 Laan til 4,115,903 Kr. (H. 2. 1.).

De tyske Frem me d menig he der har i 1930 i Haderslev Amt holdt 101 Gudstjenester, 67 Menighelsaftener og 36 Kvindemøder i 9 Menigheder med over 8000 Deltagere i samtlige Foranstaltninger mod højst 1000 i 1925 (H. 6. 1.). I Haderslev dannes en ny Fremmedmonighed. Det beklages af de tyske Menighedsraadsmedlemmer i alle 13yיr (H. 8.,9.,12. 10.).

I Sonderborg indvieiles 24.1. en tysk Privatskole (H. 27.1.). I)r findes 11 saadanne i Aabenraa og $\&$ i IIaderslev Amt. I Aabenraa bar den $31 \%$ Elever (40 Fremgang.) I Haderslev er Antallet af Elever lat den højere Privatskole vokset fra 28-30. Vilstrup har 74 , Sommersted 57 Elever. I Slogs Herred er der 13 tysk- og 24 dansksprogede Skoler med henholdsvis 371 og 883 Elever (H. 16.5.) Tyskerne i Aabenlaa kræver af Byen 9, Liererkollegiet ved den tysksprogede Folkeskole i Aabenra havder, at deres danske Kolleger, der er 1:3, arbejder loyalt (H. 16. 3.). Overlar- 
rer Jepsen i Aabemaa siger, at der ikke er $20 \%$ af Borneme, der kan forstaa Tysk, naar de kommer til Skole i den tyske Kommuneskole (II. 19.3.).

Paa de tyske Folkehøjskoler i Rendsbory, Lak, Maarkar(1sterskov og Tinglev er rle fleste Hlever fra Nordslesvig. (Av. 31.4.).

\section{d. Danski Nordslesvig.}

Det danske A a r mode fandt Sted i Haderslev den 5. Juli. Sprogforeningen havde 1930--31 12,635 Medlemmer (975 Fremgang), deraf 6ะ8i i Sønderjylland. Her var Antallet gaaet 124 tilbage, men norden Aa var vundet 10\%9. Den har til Granseomraadet udsendt 2105 Bind Boger til Bogsamlingerne, fordelt 9:395 Bind og Hafter til Jul og støttet Forsamlingshuse med 8,(991 Kr. samt Arbejdet syd for Grænsen nued 6,140 $\mathrm{Kr}$.

Sprogforeningen har nu $94 \pi$ Tillidsmand, deraf 352 hernede (H. 12. 1., Ber. 30'31.)

Sk o 1 ef oreningen havde ca. 20,000 Medlemmer, deraf 12,456 her i Nordslesvig. Den havde støttet 282 Elever fra Nordslesvig og 81 Syd fra (II. 6.7., Av. Nr. 155, Ber. 30-31.).

Grans eforeninge $n$ for Sonderbolg Amt er fra 612 Medlemmer vokset til 13:5 (H. 2. 2.) I hele Landet har Foreningen 44,785 Medlemmer mod 42,983 i 1930. Den holdt Sendemandsmøde i Kolding 15. og 16. 5. (Ber. 1931, Gr. \$. 156 ff.).

La n d evær net har haft et gollt Aar, men savner dog Kabere. Generalforsamlingen urltaler Onsket om, at det dinske Folk forstaar, at Landeværnets nationale Opgave har varigt krav paa og faa Aar til Aar paakræver Støtte fra hele det danske Folk (H. 4.3.).

Ved Nytaar holdtes som sadvanlig et stort Ung d o mis m b d e i Haderslev (H. 3. og 4.1.). I'ala Afstemningsdagen holdtes der Fester rundt om i Landsdelen (H. 11. 2. ff.). Ligeledes paa Genforeningsiagen (H. 16. 6.)

I Tonder Ants I d r a t s s t a ve i Jogunkloster 12.4. deltager 19 Hold (H. 8. 4.). 600 frivillige Irenge gor en Tur langs Østkysten i I'insen (II. 26.5.).

I Begyndelsen af April arrangerode sonderjydske Ma lere en Ud- 
stilling i Iladerslev (II. 1. og 7.4.). I samme Maaned udstilledes simmesteds 60 Billeder af 4 haderslevske Malere (II. 23.4.).

To n derhus er bleven ombygget for $10,967 \mathrm{kr}$. (II. 26.3.). Forsamlingshuset i Ulkebol indvies (Av. 27.1. og 3.). Ny Forsamlingssal i Visby indvies (Av. 11. 10.).

Te a t o r for en ing on kraver, at Forsamlingshusene skal melde sign ind $\mathrm{i}$ (len (II. 17. 9.).

Midt i $.19 j$ kom Kongeparret til Sonderborg paa det arrlige B esing her nede (II. 19. 5., Av. Nr. 115 ff.). 11 unge Nordmæend hesager Kobenhoved og skodborg (11. 219.6.). 30 svenske besøger Aabenraa ( $H$. 4. 7.). 20 I)eltagere i Mejarikongressen besoger Mejerier og Landbrug her nede (II. 24. 7.). Deltagerne i det nordiske Højskolemøde i Askov besoger Aabenlan og Dybhal (H. 3. og 4.9.). Hollandere besel Afvandings- og (irmolforbetringwarbejder her (H. 19, og 22.9.).

lolkentanlsulvalget agter at undersuge de sonderjydske Byniatal (H. i. 5.).

\section{Politik.}

landersbevagelsen (L. $\mathrm{s}$. = Landhrugernes Sammenslutning) begynulte ofter at have dannet Sammenslutning i 12 Amter norden Aa nu ogsata at faa Indgang i Sonderjylland, forst i Logumkloster (II. 4. 7.). Paa et Møde i Rolekro valgtes Tillilsmentl (II. 8. 7.). I lojt boykotter Mejeriot. Jamsgaard, dep havele koht en trangssolgt (Gaard (H. 15. og 17. 7.). Kyed advarer mol boykotuing (11. 26. 7.) 10\% Reprasentanter for Mejerierne i Aibemata Aut tager Afstand frit den, men opfordrel Bestyrelserne til at stotte L. S.-Bevagelsen (II. 27. T.). L. S. hat 2134 Medlemmer i Aabenraa Amt (II. 21. 8.). Den vil hinde Sparekassen i hiri-

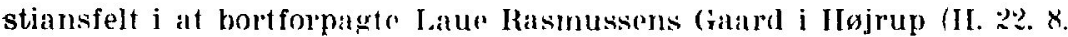
og 28.. .). Krellitforening('n vil ikke forhandle, hvis der trues med Boykott. (H. 2X. X.). Institutteme velltager at tage Kampen moll Boykottingen op (II. 5.9.). Boykotting af Bager Boysen i Rens matte haves (H. 11.9., 12.9.). Man er vell at faia Betankeligheder (H. 19.9.).

Paa et Venstremerle i Kliplev afvistes Regeringens Kriseforslag (H. 2:3. 7.). Viprdien af det droftes (II. 3. 8., 19. X.). I December lruftedes den sunderj. Krise i Folketinget (II. 11.13.). 


\section{Samfundsforhold.}

Nordslesvigs Befolkning er fra $1920-30$ vokset med $8,6 \%$ (Gr. S. 13.).

I Tønder Amts Lægekreds fødtes i $1930770 \mathrm{Børn}$, mens der d ø d e 296 (Ber. 1930). Aaret før var Tallene 810 og 362. I Haderslev Amts Lægekreds fødtes 19301095 Børn, mens der døde 584 (Ber. 1930). Aaret før fødtes 1237 og døde 585. Haderslevs Indbyggerantal er siden Nov. 1930 vokset med 341 (H. 10. 12.). Tønder er fra 5609 1. 1. 31 gaaet ned til 5515 1.10 (Av. 10.10.).

Der er 1930 oprettet ca. 150 nye $\mathrm{H}$ us in a $\mathrm{n}$ a s b r u g i Sønderjylland, siden Genforeningen ca. 1000 (H. 3. 1.). Af Werthemine fordeltes 27.2. 26 nye Brug og 12 Parceller (H. 28. 2.). I Rougstrup udlagges 6 nye Brug (H. "2. 3.). I Kassø køber Jordlovsudvalget 300 Tdr. Land (II. 16. 6.). Ligeledes har det købt Refsø med 39.' ha (H. 25.3.). I Brons har det kubt ca. 100 ha (H. 4.6.). Jordlovsulvalgets Udstykning hernede kritiseres i Folketinget (H. 9. 4.). I Landstinget fremsætter Jefsen Christensen et Lovforslag, hvorefter de forskellige Udstykningslove ligestilles og Overtagelsessummen efter Loven af 4.10. skal være i Overensstemmelse med Jordens Handelsværdi. Landbrugsministeren afviser imidlertid Forslaget (H. 28.3., 31.3.). Den sønderjydske Udstykningsforening har som Følge af de daarlige Tider sidste Aar kun oprettet én Ejendom (H. 23.5.).

Staten mageskifter Refsø med Haves Gaard paa Aarø. De 130 Tønder Land skal udstykkes (H. 1. 8.). Domanen Taaggerup med 179 ha blev solgt til Have, Hørregaard, for $180,000 \mathrm{hr}$. (H. 6. 8.).

Niels Frederiksen siger, at Jorden her er for dyr. Callø paaviser, at det ikke er rigtigt, og Jefsen Christensen hævder, at der til Udstykning maa gives Dagens Pris for Jord (H. 6.3.). Callø kritiserer Niels Frederiksens Haandhævelse af Udstykningsloven (H. 9.3, 10.3.). Denne søger ved Husmændenes Sendemandsmøde at forsvare sig. Ved samme Lejlighed anker en Husmand over, at Statshusmændene intet Steds kan faa Laan (H. 15.6.). Callø slutter Ordskiftet med at beklage, at Landbruget ikke kan vente sig nogen Støtte af Jordlovsudvalget (H. 16.6.).

Laanefonden fortsætter med den 11/2 Million, der endnu er tilbage (H. 20. 3.). 
I Haderslev, Aabenraa og Tønder Amter ammeldtes $29-30$ 13,163 arbejdsløse og afmeldtes 11,793. I 28-29 var der tilmeldt 10,931 (H. 26.6.). Midt i December var der over 4000 arbejdsløse i Sonderjylland, $2 \frac{1}{2}$ Gange saa mange som til samme Tid i Fjor (H. 17.12.).

Døvst umme instituttet overtager Stendetgaard for at drive den som Larested for døvstumme Drenge (H. 4.3.).

Monteringen af Augustenborg $S$ indssygehos it a l vil koste 375,000 Kr. (H. 21. 3.).

Sønderborg Amts S y g e h u s skal udvides for $400,00 \mathrm{Kr}$. (H. 15.6.). Imidlertid tænkes det sammenlagt med Statshospitalet. Gennemforligheden af det anerkendes fra alle Sider, og Ministeriets Udvalg anser Sammenlagning for mulig allerede med de Senge, der findes (II. 1. 9., 10.9.). Man enes om den (H. 10. 12.). I Haderslev Anit er der dannet 10 nye Sygeplejeforeninger (Av, 6.6.).

I Haderslev indvies et nyt Alderdomshjem med 25 stuer, hvoraf 14 er optaget (H. 30.1.). Aabenraa vedtager at bygge et for 58,000 Kr. (H. 23. 4.). I Sønderborg indviedes et (Av. 10.5.).

S y geforsikringen "Sønderjylland" har nu 2607 Medlemmer (H. 30. 3.).

Den sønderjydske U l y k k s forsi k ring skal afvikles. Fonden har 863,926 Kr. Formue og Renterne beløber sig til 716,547 Kr. (H. 27. 4.).

Krigsinvaliderne klager over, at 2,220 Ansøgninger er afslaaet, mens kun 821 er bleven henlagt (H. 28.3.). Paa Generalforsamlingen klages over, at Understøttelserne siden 19:2 er skaaret ned med ca. 2 Mill. De kræver tvungen Sysselsættelse (H. 11.5.).

Zoneredningskorpset faar Stationer i Haderslev, Aabenraa, Sønderborg og Tønder (H. 6. 5., 3. 8., 4. 8., 17. 8.).

Hovedparcellen af $\mathrm{D}$ om $æ \mathrm{n}$ en Werthemine er bleven solgt til C.hr. Ravn fra Dons for $155,000 \mathrm{Kr}$. (H. 6. 3.).

Den nordsl. Kvindeforen ing har haft god Fremgang i Medlemstal og Bidrag (H. 4.6.).

I Haderslev Amt er der 14 frivillige B r a n d v a r n med 445 Medlemmer (H. 29.6.).

Den alsiske Brandkass e for Losøre har i 1930 erstattet 34,400 Kr. Den har 113,000 Kr. Kassebeholdning (H. 21.9.). 
Sonderjydsk F on 1 har i 1930 anvendt $218,000 \mathrm{Kr}$. til Hjælp. Den ejer cndnu 2,389,839 Kr. (H. 19. 12.).

l)ansk Arbejdsmandsforbund erklaerede s trejke i Haderslev, fordi $T$ af dets Medlenmm var bleven fast ansat (II. 18., 19., 27,, 28., 31. 8. og 1.9.).

\section{Erhverv og Okonomi.}

a) L a n d brug.

Der er siden 19:0 afvandet og grundforbedret 36,000 ha hernede (H. 8. 12.). Ved A f vandinge $n$ af Tondermarsken er der opnatet gode Rosultater, men der mangler Kapital til ret at udnytte den (14. 29. 4.). Det tyske Dige langs Vidanen og Rudbol Sø sprangtes sonı Fulge af lang Paalandsstorm med Højvande (II. 20. 1. Av. 20. 1.). Brede aadalen oversvommedes, saa at Vandet ved Ulstrup stod tat op til Gaarlene (II. 21.8.). Marskjorden gaar ned i Pris. En Fenne, dor i Fjor kostede 81, koster i Aar kun $60 \mathrm{Kr}$. Dematen (H. 26. 3.). I M e rgelselska bet for Logumkloster Omegn er dor tegnet $80,000 \mathrm{~m}^{: 3}$ (H. 26.1.). Det for Vojens og Omegn har udkort 109,648 $\mathrm{m}^{3}$ (H. 5. 10.). Der er siden 1920 grundforhedret 36,602 ha med 7,315,000 Kr. Beknstning (L. S. 419.).

J ord fordelings kommissionen har medvirket vel ombytning af 50$) 2\{$ larceller med 9696 ha Land (Av. 7.6.).

Sinderiydsk Fallesledelse for Avlen af roft dansk Malk ckvarg hat bestaact i 10 Aar. I)yrene or i den Tid bleven mere velhyggede, de kontrollerede kiors Ydeevne er steget genmemsnitlig 25 :30 kg Sumer pr. Ko. Deres Antal er nu 2-3 Gange stuple end for 10 Aar siden (L. S. 55. II. 15. 1.). Der er 41 Kontrolforeninger. Kompes Antal tr 13,81\%. Smorualbyttet 153,6 kg pr. Ko.

I Mejeriforeningen or der 132 Mejerier. De monlog rigelig 23 Millionel kg Marlk mere end 1929 (L. S. 70 ff.).

Dot gennemsnitlige Lelbytte pr. Ko or i de 10 Aar steget ined 74k kg Marlk, 0,10 pCt. Feilt og 34 kg simør (H. 20. 1.).

Forlesledelsen af Korthornsavl omfatter ca. 1700 besatnin-

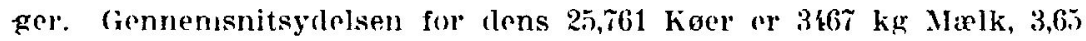
pC. Forlt og 141,3 kg smor. I)er ey $1,5 \mathrm{~kg}$ Flemgang i smor fra sidste Aar, 15 kg i de sillste 3 Aar. (I. S. 8.25.). 6 Tyre or kght i England (11. :. 1:.). 
Direktøren for Landbrugskamret i Kiel, Thyssen, siger, at i Tyskland er kun 10 pCt., i Slesv.-Holst. 24 pCt., men i Dannark dobbelt sad mange af Køerne under Kontrol (H. 31. 8.).

Paa Udstillingen af jy d $\mathrm{s}$ e $\mathrm{M}$ e jerier naaede Sønderjylland 11,16 Points mod 11,3 som Gennemsnit (H. 5.3.). Paa Lands udst i 11 i n g e n fik Haderslev Amt gennemsnitlig 10,97, Sønderborg 11,25, Aabenraa 10,82 og Tønder Amt 10,54. Landsgennemisnittet var 11,09 (H. 13. 7.).

Der er her 15 Privatmejerier. Deres Produktion ligger i Kvalitet under Gennemsnittet. De 5 af dem ligger i Byerne. Af Resten ligger de 6 i Tønder Amt. Holdes de uden for Opgørelsen, kommer Tønder Amt ved Laboratoriets Bedømmelse op paa Gennemsnitskvalitet (H. 6.3., L. S. 171.). Tønder Amt hlev Nr. 1 ved en Smørudstilling i Tinglev (H. 7. 10.).

K væg t uberkulosen er hemele saa slem, at kun $5-6$ pCt. af de undersøgte Besætninger har varet fri for den. En Forening dannes til Bekæmpelse af den (H. 12.6., Av. Nr. 135.).

Der dannes en Kreatur-Eksportforening for Nordslesvig til Afsætning af Fedekvæg, foreløbig især til Belgien (H. 14. 7.).

Sønder Vilstrup M jeri, der begyndte 1898, senere deltes i et tysk og et dansk men dog atter samledes, er nylig bleven ombygget og udvidet. Det begyndte 1898 med 1,8 Mill. Pund Mælk, men venter i Aar at komme op paa 7 Millioner (H. 24. 8.).

Sønderjydsk Smøreks portforening har i 1930 modtaget 73,436 Tønder Smør mod 66,161 Aaret før (H. 28. 10.). Til Haderslev Smøreksportforening er indleveret 26,717 Dritler Smør, 8 pCt. mere end 1929 (H. 31. 10.). Sønderjydske Landmænds' Smøreksportforening har modtaget 77,685 Dritler $\bmod 68,576$ Aaret før (H. 9.11.).

IIaderslev Fjerkræavlerforening har nu 300 Medlemmer imod 51 i 1920. Oprettelsen af et $\mathrm{F}$ jer $\mathbf{k}$ r $\mathbf{s} \mathbf{l}$ a $\mathrm{g}$ teri er nu sikret. Der er tegnet ca. 40,000 Dyr (H. 24.3.). Det oprettedes 16.8. Det skal ligge i Haderslev og omfatte Sønderjylland og Vejle Amt. Der er tegnet ca. 50,000 Dyr (H. 17. 8.). Ved Nytaarstid var der slagtet ca. 9000 (H. 31. 12.).

Paa Rømø holdes endnu mange F a a r, tilsammen 3000 . I Foraaret (1931) var der fra Fastlandet bleven indslebt Mund- og Klovsyge. 
med Faar. Heldigvis viste det sig dog, at ingen var bleven smittet. (H. 8. 8.)

Slagterierne (Haderslev og Skærbæk ikke medregnet) har haft en samlet Stigning af 93,861 Svin og er nu paa 360,000 (H. 2. 1.). Aabenraa har slagtet 87,453. Det vil oprette en Blodfoder- og Benmelsfabrik (H. 2. 2.), Vojens 30,944 (H. 13.2.), Rødding 36,193 (H. 20.2.), Graasten 72,000. Det har 1100 Andelshavere og skal udvide (H. 28. 2.), Sønderborg 79,000, Tønder 22,747 (H. 30.3.), Skærbæk 30,032, Bylderup-Bov 25,650 (H. 8. 4., Av. 8. 4.).

Oversigt gives over Høst u d by t te t 1930 (H. 25.6.). De hjemmeavlede Foderenheder er for Tiden det eneste Lyspunkt (H. 27.6.). Sukkerroearealet i Haderslev Amt er fra 620 Tønder Land gaaet ned til 400 i Aar (H. 15.5.). Engene paa Rømø hærges for første Gang af Orm (H. 27.5.). Smaaskovsforeningen for Aabenraa og Sønderborg Amter har nu 248 Medlemmer med 1185 ha Skov (II. 16. 7.). Af L and b r u g sare a let er siden 1920 Korn steget med 8 og Rodfrugter med 3 pCt., mens Brak er taget af 2, Græs i Omdriften med $1 \mathrm{og}$ udenfor Omdriften med 8 pCt. Kornudbyttet er forøget med 29 og Roer med godt 36 pCt. (H. 18. 9.).

Landbrugets Forrentningsprocent udgjorde i $30-31$ i Regnskabsforeningerne i Aabenraa Amt $\div 0,8$ pCt. (H. 6. 10., Ber.), i Haderslev Amt 0,75 mod 4,1 i Aaret før (H. 17. 3.), paa Røddingegnen har Underskuddet været 74, i Als Nørreherred $94 \mathrm{Kr}$. pr. ha. (H. 18. 8., 18.11., 16. 12.).

Gartner Jacobsen, Aabenraa, gor Forseg ned kunstigt lys i Drivhuse (H. 27. 11.).

I første Halvdel af 1931 var Kvægudførslen til Tyskland 86,3 pC.t. mindre end i samme Tid 1929 (Av. 9.10.).

\section{b. Industri og H a a n $\mathrm{d} æ r \mathrm{k}$.}

Højspændingsværk $\theta$ t har i 1930 frembragt ca. 13 Millioner kwh, 2,3 Mill. mere end Aaret før (H. 2.1.). Produktionen er næsten tredoblet siden Starten (H. 2. 6., 3. 6.). Det faar indlagt den største Turbine i Danmark uden for København. Den er paa 20,000 Hestekræfter (H. 5.8.). Man undersøger Muligheden for Samarbejde mellem Aabentaa og Aarhus Højspændingsværker (H. 14.8.). Høj- 
spandingsvarket har et Iniftsoverskud pai $250,000 \mathrm{Kr}$. (Av. 3.6.). Under en Snestorm kom ca. 200 af Varkets Transformatorstationer ud af Forbindelse med det. Ogsaa de fleste Telefonforbihdelser blev afbrudt (H. 5. 1.).

I Tyrstrup Herreds Elektricit e tsselskab er Lysforbruget steget med 15,5, Landbrugskraft med $33,7 \mathrm{og}$ Hawndvarkskraft med 17,4 pCt., strømmen til Husholdning med 47,3 pC.t. (H. 28.3.). I Sønderborg og Aabenraa Amters Elektricitetsforsyning er Strwmsalget steget med 23,5 pC.t., i Midtsønderjyllands med 36 pCt. til Lys, 38 til Iandbrugskraft, 8,9 tỉl Haandværk og 9,4 til Industri. Priserne falder ved det stigende Forbrug (H. 4.6., Av. Nr. $126 \mathrm{cg} 127$.$) .$ Haderslev Nas' Elektricitetsforsyning indtræder i Hajspandingsverket som Andelshaver (H. 11.7.). Tander afviser Hojspendingsvarkets Tilbud om Stromlevering og vil udnytte Vandmallens Kraft samt kube en Dieselmotor (H. 15. 18.).

Arskilligt tyder par va a genda I,ivlighed i flere Industrigrene i 1930 og i Lobet af 1931 De sammensluttede Teglvierker paa Broagerland har solgt dobbelt saa mange Sten i 1930 som i 29 , nemlig 40 Millioner (H. 31. 1.). Tonder Aktiebryggeri har 17,109 Kr. Overskud og giver 5 pCt. Dividende (II. 20.3.). Oljemøllen i Sønderborg er igen kommen i fuld Drift (H. 19.5.). Margarinefabrikken "Bona" i Sønderborg vil udvide for 60,000 Kr. (H. 8.9.). Gram Teglværk skal have en Gravemaskine (H. 17.9.) I Aabenraa indrettedes Danmarks anden Glødelampefabrik (II. 18.9.),

Orgelbyggeriet i Aabenraa, det xldste i Danmark, fejrer i Aar 125 Aars Fest (H. 30. 10.). I Gram brændte Tæppefabrikken. Der brændte for $1 / 4$ Million Kr. (H. 12. 11.). Et tysk Firma onskede at bore efter Sait ved sønderborg, hvor man mente at kunne udvinde 100,000 Tons aarlig. Der fremsattes og vedtages i den Anledning en Lov om, at Staten har Eneret til Efterforskning og Udvinding af Raastoffer i Danmarks Undergrund (H. 28. 1.1., 2.12., 12.12.).

c. Handel og Skibsfart.

Handelsforeningerne $i$ de 4 sønderjydske Byer advarer paa et Møde i Aabenraa imod at lanne Akk ordforeninger (II. 20.3.). Det vilde undergrave Tilliden, siger sønderjydske Købmands Dele- 
geretmøde i Graasten (H. 11.5.). Trafikken paa de sønderjydske H a vne var i April Kvartal paa Højde med 1930 (H. 7. 10.). I Juli Kvartal havde de paa Graasten nær lidt Fremgang (H. 8. 12.). Aabenraa Havns Indtægter er firedoblet siden 1921. Godsmængden er vokset fra 55,003 til 170,930 Tons (H. 11.4.). Aabenraa Eksportmarked er i Opgang igen (H. 31.7.). Den sonderjydske $F$ is kerfla a d e over 5 Reg. Br. T. omfatter 81 Baade paa tilsammen 651,75 R. Br. T. og med 827 H. K. (H. 17. 12.).

d) Pengevæsen.

Nogen Fremgang var der i Bankernes Virksomhed i 1930. Løgumkloster Bank gav 71/2 pCt. Dividende, (H. 4.2.). Folkebanken for Als og Sundeved 6 pCt. (H. 9.3.). Graasten Bank 8 pCt. Dens Omsætning er steget med 5 Millioner til 150 Millioner (H. 9. 3.). Haderslev Bank giver $10 \mathrm{pCt}$. og har 152,664 Kr. Nettooverskud. Indskuddene i den er vokset med $620,000 \mathrm{Kr}$. (H. 16.3., 18. 3.). Den nordslesvigske Folkebank giver 7 pCt. (H. 16.3.). I Rødding Bank er Indskuddene stegne med 102,000. Den giver 6 pCt. Balancen er 116,628 Kr. (H. 27.3.). Tønder Landmandsbanks Omsætning har været 197 Millioner. Dens Status er 5,761,577 Kr. (H. 13.4.).

Ogsaa i Sparekasserne voksede Indskuddene. I Frøs og. Kalvslund Herreders Sparekasse med 222,000 til 21/2 Million (H. 1.6.), i Aabenraa Byes med ca. 1/2 Million, Tinglev 58,000, Kliplev ca. 24,000 (H. 29.6.). I Nørborg Sparekasse steg Indskuddene fra 2,473,688 til 2,590,473, Sparerne fra 2157 til 2216 (H. 29.7.). Løgumkloster Sparekasse blev 110 Aar gammel (H. 13.1.). Haderslev Spareforening har ca. 800 Medlemmer. 54,000 er udbetalt i Sparepenge (H. 28. 3.).

La a nekassen vil kun i yderste Tilfolde gaa til Tvangsauktion. En Del Laantagere kræver dog baade Henstand og Valutaregulering (H. 16.3.). Den flyttes 1.10. til Tønder (H. 1.7.). Dens Reservefond styrkes (H. 28.11.).

Sønderjyllands Kreditforening standser Udlaanet i 5 pCt. Serien (H. 30.3.). Der er seks Gange saa mange Tvangsauktioner her som i det ovrige Land (H. 7.8.) I Aabenraa Retskreds har Kreditforeningen maattet gøre Udlæg i 30 Ejendomme (H. 1.12.). Allerede i Oktober havde den $\mathrm{i}$ hele sit Omraade overtaget ca. 50 Ejendomme 
(H. 26. 10.). Et Debitormøde svarer den, at den ikke kan anbefale Moratorium og Standsning af Tvangsauktioner (H. 2.11.).

Husmandskreditforeningen, som har Laan i ca. 5000 Ejendomme i Sønderjylland, havde den 20. 8. overtaget 5 Ejendomme, og $\mathbf{i}$ Aarets Løb vilde højst 20 af dens Panter komme til Salg (H. 25. 8.).

I Nørreløgum fandt Sognet paa at sætte private Penge i Omløb til et Beløb af 10,000 Kr. (H. 27.7.). Skattedepartementet kræver Sedlerne stemplet for $1 \mathrm{pCt}$., mindst 10 ore (H. 28. 7., 29. 7., 21.8.). Flere Steder blev de indført (H. 14.9.) men efter et Par Maaneder gik Foretagendet i Staa paa Grund af Valutasituationen (H. 29. 9.).

Stor Forstyrrelse voldte det, ogsaa her, at England gik fra $\mathrm{G} \mathrm{u} \mathrm{l} \mathrm{d-}$ foden og Danmark fulgte det men ikke straks ordnede Forholdet (H. 21.9. ff.).

En Bevægelse, der kaldte sig "H j e m m evær n e t«, og som krævede Standsning af Tvangssalg, Moratorium og Valutaregulering (H. 16.3.) fik ikke synderlig Tilslutning (H. 31.3.).

e) S a m kve m.

Med S ma a banerne ganr det stadig tilbage. Paa Als gav de 4,263 Kr. Underskud i Stedet for det beregnede Overskud af 4,300 Kr. (II. 13.6.). Driftsbestyreren ser i sit Memorandum meget pessimistisk paa Banerne. Amtsraadet henlægger et Projekt om normalsporet Bane til Mommark og vil paa visse Betingelser søge om højere Tilskud til Modernisering af Banerne (H. 11.7.). I Haderslev Amt er det værre. Der vil Underskuddet naa op til 300,000. Sogneraadsforeningen kræver derfor Banerne nedlagt (H. 28. 8.).

Paa Statsbanen bliver Middagsekspressen fra Padborg Danmarks hurtigste Tog (H. 23.3.).

Landevejene ofres der stadig mere paa. Haderslev Amtsraad vedtager Vejen til Esbjerg og vil have den ført fra Nørre Hjarup over Bevtoft, Nustrup, Østerlindet, Hygum. Den vil koste det ca. 1/2 Million (H. 8.1., 27.1.). Af Vejfonden faar IIaderslev Amt 210,010 Kr. til en Del store Vejarbejder (H. 16.6.). I det hele faar Sønderjylland ca. 2,3 Millioner (1I. 27.7.). Haderslev Amt vil faa 59,500 Kr. og Sogneraadene i Amtet 313,200 Kr. Tilskud til Vejarbejder (H. 3.9.). Kjelstrupvejen alene vil koste Amtet og Byen ca. $1 / 2$ Million 
(II. 19. 10.). Vejen fra Itjelmrode til Hjordkir er nu færdig (H. 10. 10.). Den fra Aabenras til Esbjerg anse's nu for sikret (II. 16. 10.). Ved Løgumgaard blev en ny Bro taget i Brug (Av. 10.10.).

Rutebilerne faar stadig større Betydning. Aabenrau Auto. mobilselskab har haft $108,640 \mathrm{Kr}$. Indtægt af Beforlring. Det giver 5 pCt. Dividende (II. 21. 2.).

Ved Ragebal blev en Mand dræbt ved sam menstod mollem Bil og Tog. Der findes alene paa Sønderborg-Tinglevbanen 30 ubevogtede Overkørsler (H. 4.6.).

Et 100 km langt Telefonkabel nedlægges fra Kolding til Krusaa og fra Aabenraa til Sønderborg (H. 22. 4., 30.6.).

\section{Kommunalt.}

A a benra a u d k river i 193123,000 Kr. mindre i personlig skat end i $1930 \mathrm{og}$ afbetaler $480,000 \mathrm{Kr}$. Gæeld (H. 29.1.). Skatteprocenten gaar fra 8 ned til $71 / 2$ pCt. Der er 4588 skatteydere (II. 26.3.). I H a d erslev sattes en Del Arbejde i Gang for at mildne Krisen (H. 4. 2.). Ligningsprocenten gaar fra 7,5 ned til 7,2 . Den begyndte for 7 Aar siden med 12,2 (H. 19.3.). Gælden er gaaet ned med ca. $170,000 \mathrm{Kr}$. (II. 23. 10.). Søn derborgs Budget or paa 1,181,134 Kr. (II. 5. 2.). Vandværket skal udvides for $80,0(0)$ Kr. (H. 29.5.). I T ønd e r er Skattebehovet gaaet 31,000 op, til 431,000 Kr. (H. 7. 2.). Alligevel gaar Ligningsprocenten fra 10,6 ned til 10,3 (H. 28.3.).

Tøn der Amts Skatteudskrivning blev som Aaret for 600,000 Kr. (H. 25. 3.). Aubenraa Ants gik fra 560,000 ned til 520,000 Kr. (H. 25. 3.).

Haderslev Vandværk kan levere dobbelt sau meget Vand, som der bruges paa de varmeste Dage (H. 2.6.).

\section{Menighedsliv.}

I Nørborg meldte 49 Skatteydore sig ud af Folkekirken (H. 23. 1.) I Sønderborg derimod, hvor Tyskerne ved sidste Valg vandt en uforholdsmæssig Del af Repræsentationen, fordi saa mange Danske ikke havde meldt sig til Valglisterne, har 2100 ny Valgere meldt sig, saz at Antallet nu er 4500 (H. 24.9.). I Rinkenæs er den nye Kirke snart færdig. Der fortelles om dens Tilblivelse (H. 18.5.). Provst Biering i Sønderbory blev den 26.4. indsat som Præst i Dybbøl (H. 27.4.). Den tyske Sognemenighed i Harlerslev opfordrede Pastor Prahl i Flens- 
borg til at søge Embedet (H. 14.10.). Han lovede det (H. 15.10.) og blev enstemmigt indstillet. Danskerne stemte ikke. (H. 26.11.). Den nye Lønningslov sætter et Par Hundrede Præsteembeder i 3. Kilasse. Menighedsraadene i Sønderjylland beder om ikke at nedsætte mange her nede, da Forholdene her kræver, at en Præst kan blive længere Tid paa Pladsen (H. 22.6.).

P ins e $m$ øde $t$ i Tinglev var meget stort (H. 27.5.). Kirkelig t s a m f und holdt Mode i Tonder (H. 28.5., Av. Nr. 121). Sommermødet i Vedsted var stærkt besøgt (H. 14. 7.). Øst Jeypooremissionen overgaar til Nytaar 1932 til Dansk Missionsselskab (H. 10.9.).

\section{Oplysning.}

Larerforeningerne anbefaler den nugældende sønderjydske Ordning med smaa Skolekommissioner (H. 12.1.). Ved de ministerielle Standpunktprøver viser det sig, at de sønderjydske Skoler staar meget smukt (H. 19.2.). Tonder Amt blev Nr. 2 i Genfortælling og Nr. 1 i kogning (Av. 17.2.).

I Skolerne i Tonder Amt var der

$\begin{array}{lrl} & 1929 & 1930 \\ \text { tyske Elever } & 983 & 1056 \\ \text { danske Elever } & 3933 & 4164 \text { (Ber. 1930). }\end{array}$

I Vesterende-Ballum indvies en ny Skole (Av. 12.10.).

I Skolerne i Slogs Herred har der siden 1925 været procentvis tysk Fremgang i Børneantallet i Burkal, Bylderup og Tinglev Sogne (Av. 19.4.). Lydersholm fik en ny Forskole (H. 5.10, Av. 233).

I Haderslev Amt gik 7180 i dansk-, 460 i tysksproget Skole, af de sillstnævnte 371 i Byen (I. 23. 3.) (Ber. 1931). I Sønderborg Amt gik 4639 i dansk og 678 i tysk Skole (Ber. 1931). En ny Skole indvies $\mathrm{i}$ Augustenborg (H. 19.1.). Af Statsskolerne havde Sønderborg 296 Elever, 26 bestod Studentereksamen (Ber. 31.). Haderslev havde 314. Paa den tog 26 studentereksamen (Ber. 31.). Tønder 204, 15 tog studentereksamen (Ber. 31.). Fra seminariet i Haderslev udgik 28, (II. 12.6.), fra Tonder 24 nye Lærere (H. 16.6.).

I Aabenraa Amts 67 skoler gik i 19305239 Børn, deraf 4502 i danske Skoler. Af de tysk underviste gik 635 i Privatskoler (H. 24.4.).

1 Tonder Amt er der 48 A f te $n \mathrm{sk}$ oler $\bmod 38 \mathrm{i} 1930$ (H. 28. 3.). 
Noget enestaaende var, at Danmarks Lærerforening b l o k e r e de Embedet i Rise, fordi Læreren var bleven fjernet efter Forlangende af samtlige Forældre, Skolekommission og Skoledirektion (II. 16.5.).

Af hidtil 600 Elever paa Graasten Landbrugs $\mathrm{k}$ ol e har 415 eller 70 pCt. været fra Sønderjylland (H. 27.7.).

Folketinget vedtog med 74 Stemmer mod 23 (deriblandt de konservative) at lægge Landsarkivet i Aabenraa (H. 12.2., 21.2., 7.3., 13.3.). Ved 3. Behandling vedtoges det med 103 Stemmer (H. 14.3.). Svend Aakjær udtaler sin Glæde over, at Sønderjylland faar sit eget Arkiv (H. 7.4.).

Historisk Sam funds Medlemsantal er vokset med $22 \mathrm{og}$ er nu 702. Det har Medlemsbidrag til et Beløb af $3800 \mathrm{Kr}$. (H. 21.9.). Historisk Samfund for Als og Sundeved har 153 Medlemmer og $984 \mathrm{Kr}$. Indtægt. (II. 26.3.).

Sonderborg B ibli o te k har 14,000 Bind, 49,955 Udlaan til 2826 I.aanere (H. 9.5.). Tønder Bibliotek har udlaant 40,119 Bøger (H. 21.5., Av. Nr. 116.). Landsbiblioteket 23,615 Bind og udlaant 53,538 til 2322 Laanere (H. 21.5.). Rødding Bibliotek har 8809 Bind og 20,000 Udlaan (H. 2.6.). I Vandrebogsamlingen er indmeldt 81 Klasser. Bogsendingernes Antal er nu 159 a 20 Bøger (H. 1.6., Av. Nr. 124). Haderslev Centralbibliotek har udlaant 46,015 Bind. Det er 1372 Fremgang (H. 30. 10.). Det udsender en Bogbil, der kan medtage 550 Bind. Denne Indretning har vakt Opsigt bade i Norden og Tyskland (H. 1.8., Av. Nr. 124).

Den sønderjydske $\mathrm{T}$ e a $\mathrm{t}$ e $\mathrm{r}$ f o rening omfatter nu 60 Foreninger med ca. 10,000 Medlemmer (H. 21.5., 3.6., Av. Nr. 117). I Tinglev gav Teaterforeningens Forestillinger Balance (H. 19. 5.).

A. Bjerrum har optegnet 9000 danske Ord i Fjolde, Svesing og Olderup (H. 23.9.).

Markus Lauesen udgiver: »Og nu venter vi paa Skib» (H. 2410.)

Professor Scheel kalder Hedeby Nordens Gibraltar. Bynavnenr" stammer fra det svenske Herredømmes Tid (Av. 20.2.).

\section{Ret og Forvaltning.}

I Hoptrup prøvede et Par Medlemmer af Skolekommissionen at omstøde Flertallets Indstilling til Ixererembedet (H. 21.5.) 
Amtmand Lundby udnævnes til Stiftamtmand i Haderslev og Amtmand Thomsen i Aabenraa til Amtmand for Aabenraa-Sønderborg Amter (H. 26.5., Av. 24. 5.)

Efter mange forgæves Forsøg lykkedes det Politiet at fange Storforbryderen Antoni Lund Natten til 30. 8. (H. 31. 8.)

\section{Pressen.}

Aktieselskabet "Hejmdal optog 44 nye Aktionærer (H. 27.6.). Terkelsen, Danebod, foreslaar Oprettelse af en Journalisthøjskole (H. 30. 7.) Dybbølposten overtager Sønderborg Amts Bogtrykkeri, som havde forpagtet Bladet. Selskabet, der ejer Bladet, har allerede for nogen Tid siden nedskrevet $\sin$ Kapital fra 100,000 til $10,000 \mathrm{Kr}$. (H. 20.8.). Mod Aarets Slutning overtog "Modersmaalet« Driften af "Dybbølposten", som havde lidt meget under Berlingske Tidendes Konkurrence ( $H$. 6.11.). De sønderjydske Blade tænkes registreret fra Halvfemserne op til Dato. De københavnske er for en stor Del registreret fra 1864 (H. 25. 11.).

\section{Personligt.}

H. V. Clausen fylder 70 Aar 14. 1. (H. 13. 1., 13. 2.). Dyke Nissen i Fredsted kørt over af Toget (H.9.2.). Den 104-aarige Fru Thiellesen fortæller sine Erindringer (H. 2.5.). J. M. Kylling, Flensborg, død (H. 8.5. Gr. S. 354 ff.). Stiftamtmand Haurløv død (H. 11.5.). Skovrøy fylder 80 d. 23. 6. (H. 20. 6.). Tidligere Frimenighedspræst i Aabenraa Knud Rosendal død (H. 1. 7.). Fru Laura Skrumsager død (H. 22. 8.). Pastor Thordur Tomassen død (H. 24. 8.). Gaardejer Solmer død (H. 14. 9.). Morten Pontoppidan død i Haderslev (H. 21. 9.). Gdr. Karl Lytsen død (Av. 13. 6.). P. C. Budach, Jaruplund, død (Av. 10. 7., Gr. S. 387 f).

\section{Andre Sager.}

I Grusgraven ved Ketting findes stadig nye Viking e g rave. I Januar var den 14. fundet, i November den 26. (II. 24.1., 2.11.). Ved Brovold findes en Bebyggelse fra Vikingetiden (H. 5. 10., 21.10.). Der findes Grave i Bostedvraa, V. Sottrup og Asserballe (H. 18.12.).

Vongshøj f red es, og der sikres Publikum Adgang til den (H. 16. 4. Av. 15. 4.). Lovrup Skrøb foreslaaes ogsaa fredet (H. 23. 4.). Gyvelbakken i Kollund lykkedes det ikke at faa fredet (H. 2.5., 20.5.). 236,000 
Tønder Land Privatskov er i hele Landet aabnet for Publikum (Av. 24.5.). Sønderborg Byraad var pietetløs nok til at ville sløje Brohovedskansen for at skaffe Arbejde (H. 9. 3.). Danmark har endnu 450,000 Tønder Land uopdyrket Hede (H. 2.6.). I Sønderborg rejses en Mindesten for Hans Norsk (H. 27.3.). Et frygteligt Skybrud foraarsaged. store Oversvømmelser (H. 9. 7., 10. 7., Av. Nr. 158 ff.). Firmaet Junggreen fejrer 4. 9. 75 Aars Jubilæum (H. 27. 8.). I. Hæfte af Sønderjydske Stednavne udkommer (H. 15.9.). Træk fortælles af Degneembedets Histurie 1 Ensted (H. 17. 10.). Ved Arnitlund, Gelsbro o. a. St. er 14 Oldtidshøje fredet (H. 19.10.). Tandslet Forsamlingshus 25 Aar gammel (H. 21. 10.). En Spillebank i Flensborg trækker mange til sig her oppe fra (H. 6.11., 10.11., 16.11.). En Hval fangedes ved Aarøsund (H. 12.12.). Heiselberg Paulsen fortæller Østerløgum Sogns Historie (H. 29.12.). 1 Tønder indvies et Rejse- og Ungdomshjem (Av. 31.5.). 